\title{
やや深発地震および深発地 震の発生地域, 頻度, 被害歴
}

REVIEW OF HISTORICAL DAMAGES DUE TO INTERMEDIATE AND DEEP FOCUS EARTHQUAKES

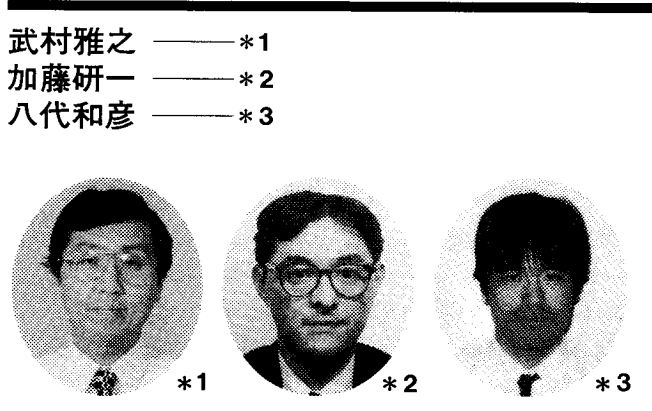

\section{Masayuki TAKEMURA \\ Kenichi KaTO \\ Kazuhiko YASHIRO}

Historical damages due to intermediate and deep focus earthquakes are reviewed on the basis of earthquake catalogs in past 100 years. These earthquakes occurred at North-Eastern and South-Western parts of the Japan islands at a rate of 4 to 5 times per year. The earthquake catalogs indicate that only the intermediate depth earthquakes, with magnitude exceeding 7.5 and focal depth shallower than 150 $\mathrm{km}$, caused destructive damages. However, the damage rank is lower than the typical interplate earthquakes along the Japan trench such as the 1968 Tokachi-oki earthquake $(M=$ 7.9).

キーワード

やや深発地震, 深発地震, 被害歴, 地震カタログ

Keywords :

Intermediate-depth earthquake, Deep focus earthquake, Damage history, Earthquake catalog

\section{1.はじめに}

地震は震源の深さによって浅発地震, やや深発地震, 媣発地震に 分けられ，その境目は $70 \mathrm{~km}$ と $300 \mathrm{~km}$ にとることが多い1)。このうち， 過去に物的・人的被害を及ほした地震の多くはプレート境界や内陸 直下の浅い地震であり，震源が深い地震は被害想定の対象に含まれ ることは少なかった。しかし，1993 年 1 月 15 日に発生した釧路神 地震（気象庁マグニチュード M=7.8）は，震源が $107 \mathrm{~km}$ と梁いにも かかわらず釧路市を中心に被害をもたらし甿を洁2)，地震工学者や地 震防災関係者に衝盤を与えた。

釧路沖地震に代表される震源が深い地震は, どのようなメカニズ ムで発生し, どの地域にどの程度の頻度で起こるのであろうか。ま た, 被害の面から過去にどのような影晦を日本各地に与えてきたの であろうか。本報は過去 100 年間に発生した深さ $70 \mathrm{~km}$ 以上の地震を 宇津 ${ }^{3)}$ の资料および地震月報に基づいて網羅的に調査し，これらの 課題を系統的にまとめることを目的とする。

\section{2. 発生メカニズム}

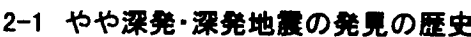

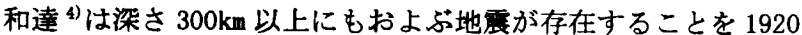

年代後半に発見し，深層地震と命名した。当時モ木面の存在は既に 知られており，通常，地震の深さは 30〜 40km でモホ面より浅い位圈 で発生していると考えられていた。これに対し，和達は深い地震の 存在を指摘し, その判別法として(1)初期微動継続時間の観測值が長 いこと，(2)等発震時線または等 P-S 線を引く時，震源が深ければ深 いほど等曲線群の間隔が広くなること, (3)深発地鹿は地震記象に特 有の型を示すこと, (4)人体感党の各地分布の異常, 地震計観測の可 能範囲が広籍に及ぶことを挙げている。

和達はその後, 更に中間的深さの地震としてやや深層地辰の存在 を指摘している ${ }^{5)}$ 。上記(1)から(4)は深層地辰について指摘されたこ とであるが, (2)(3)(4)程度の差こそあれやや深層地震においても指 摘できるとし，(1)のように走時が特定できる場合には，その確定は 容易であると述べられている5

\section{2-2 吐震機柆}

和達 4)，5) 以来やや哚発・深発地震は世界中で発見され, 浅い地 震に混じって地㫳リストにも記載されるようになる（例えば Richter $\left.{ }^{6)}\right) 。 1960$ 年代から 1970 年代にかけては, プレートテクトニ クス理論との関連で, 岛弧の地殻構造と深い地震の震度分布や発震 機構が主に環太平洋の各地で調べられた ${ }^{7}$ 。これらの調査によって 潜り込む海洋プレートの形が明らかになり，そこで発生する地屡の 
メカニズムも多くの研究者によって明らかにされてきた。

1970 年代後半には, やや哚発地震を語る上で最も重要な現象て ある二重深発地震面の発見があった。もぐり込むスラブに沿ってや や媣発地震が二重に分布することを最初に明確に示したのは，東北

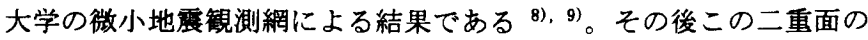
存在は北海道から関東地方まで広い範囲で潜り込む太平洋プレート に沿って確認されるとともに，その様子に地域性があることも知ら れるようになった。また同時に，東北日本で発生したやや哚発地震 の震源メカニズムも調查され，二重深発地震面の上面では地鹿を発 生させる忘力埸の圧縮軸 ( $\mathrm{P}$ 軸) がプレートのもぐり込み方向を向く, いわゆる Down Dip Compression 型（以下 DC 型と呼ぶ）のメカニズ ム，下面では張力軸 (T 軸)がプレートのもぐり込み方向を向く Down Dip Extension 型（以下 DE 型と呼ぶ）メカニズムが卓越することが 示された。これらのメカニズムを模式的に図 1 に示す。

何故, このような震源メカニズムが卓越するかについては，二重 面を形成する原因とともに幾つかの仮説が 1970 年代から 1980 年代 にかけて提唱されてきた。主なものだけでも，プレート内部の物質 の相変化 ${ }^{10)}$, プレートのアンベンデイング ${ }^{11}$, サギング (たわみ) モデル ${ }^{12)}$, プレート内部の熱态力 ${ }^{13)}$ 等様々である。近年の研究によ れば，南米のように二重面がない場合 ${ }^{14)}$ や，断層の走行がプレート のもぐり込み方向を向く場合 (Hinge Fault) ${ }^{15)}$ や，局所的に全く 異なるタイプ, 例えば正断首型等の地震が存在する ${ }^{16)}$ 等, 当初思わ れていたよりもやや哚発地震の発生様式は複雑であることが分かっ てきた。このため, いずれの仮説も全ての現象を説明するには到っ ていない。潜り込むスラブの形状を精度よく推定することや，スラ ブ内部の速度構造や温度構造の正確な推定が, 問題解決の重要な鍵 になると考えられている ${ }^{7)}$

\section{3. 発生地域と頻度}

\section{3-1 データ}

前項は樑い地震の発見の歴史, 最近の研究成果に基づく発生メカ ニズム等について説明した。このような性質をもつやや深発・深発 地震が，被害の面から過去にどのような影響を与えてきたかについ て調查する。

歴史地震では展源の深さを特定することが非常に難しいため，本 報では 1885 年から 1993 年釧路沖地震までのデータを対象とした。 1925 年以前は宇津 ${ }^{3)}$ の资料， 1926 年以後は地震月報を用い, $M=6$ 以上, 哚さ $70 \mathrm{~km}$ 以上の地震を選び出しデータセットとした。宇津の 资料では大正以前のデータに深さが数字で記载されていないものが あり，表 1 に示す記号 vs, s, d による分類がなされている。d の記载 のあるものはデータセットとしたが vs および $\mathbf{s}$ はデータから除外し た。ただし，sのうち震源が梁い地震の可能性が強く，さらに被害が かなり出たものについては，4-4 項で別途取り上げる。

\section{3-2 やや深器・深発地震の発生地城と頼度}

対象とした地震の震央分布を図 2 に示す。深さ $70 \mathrm{~km}$ 以上の地震 の発生域は北海道から東北地方さらに関東地方から小笠原諸岛に沿 う地域と，九州から琉球列岛におよぶ西南日本が中心である。この
表 1 宇津による震源深さの分類記号 ${ }^{3)}$

\begin{tabular}{|c|c|}
\hline 記号 & 意味 \\
\hline vs & $\begin{array}{l}\text { 陸側のプレート内地震で, 日本列島の内陸 } \\
\text { 部から縁海側にかけての地款中に起こった } \\
\text { ものが多く，近年のデータから類推すれば, } \\
\text { ほとんどが深さ } 0-15 \mathrm{~km} \text { 程度である。 }\end{array}$ \\
\hline$S$ & $\begin{array}{l}\text { プレート境界またはその近くの地震で内陸 } \\
\text { 部ではほとんど深さ数十 } \mathrm{km} \text { のマントル内 } \\
\text { 地震であろうが, 海溝寄りではより浅いも } \\
\text { のが多いと思われる。 }\end{array}$ \\
\hline$d$ & $\begin{array}{l}100 \mathrm{~km} \text { 越える深い地震であるが, 数値で } \\
\text { 示すほど哚さが良く決まらないことを示す }\end{array}$ \\
\hline
\end{tabular}
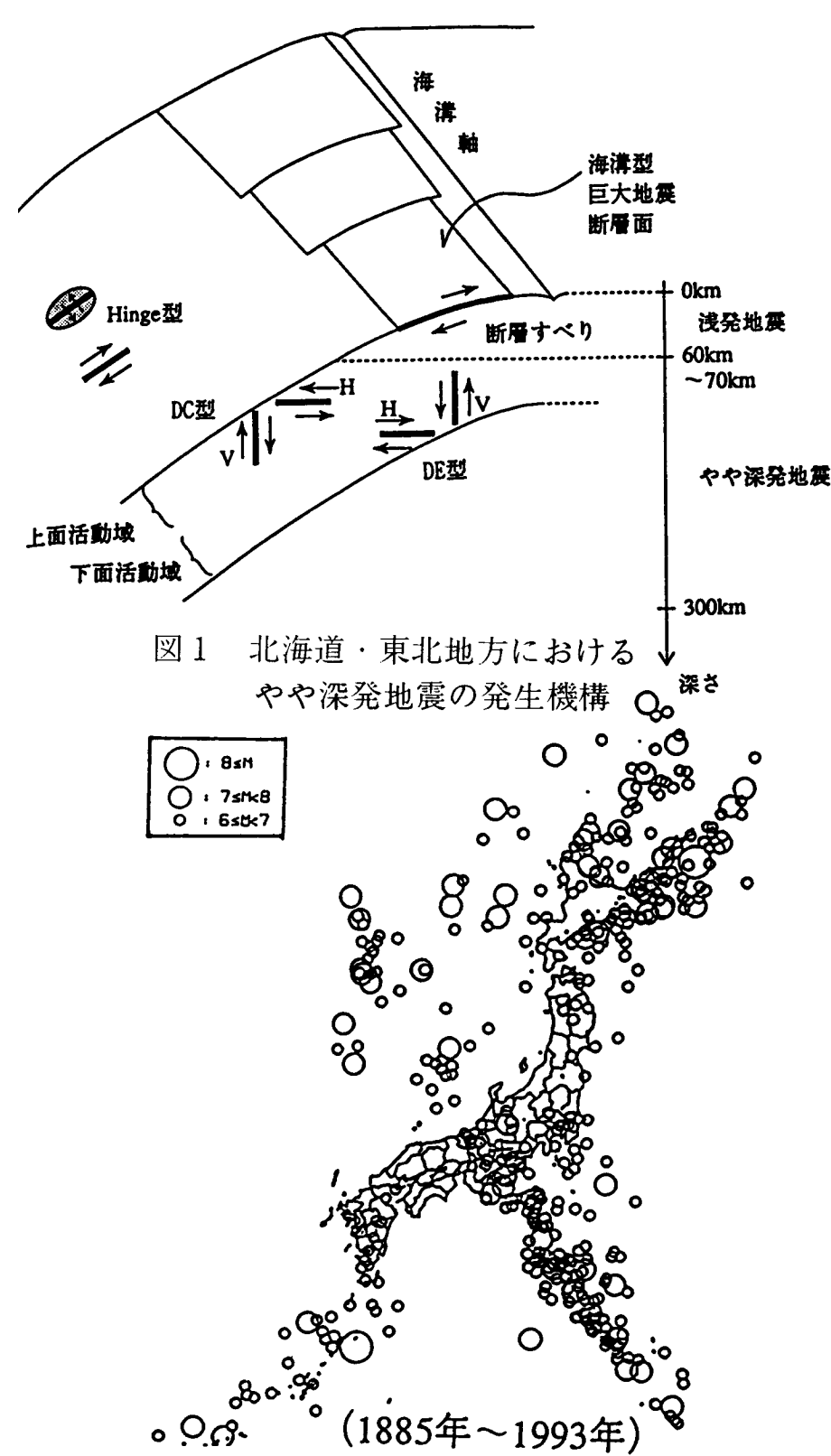

図 $2 M \geq 6$, 媣さ $\mathrm{D} \geq 70 \mathrm{~km}$ の地震の震央分布 
うち、北海道から関東地方にかけては，2-2で述べたようにやや深

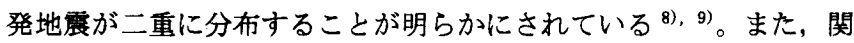
東地方では二重樑発地震面の他に，フィリピン海プレートと太平洋

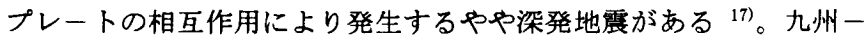
琉球列岛はフィリピン海プレートのもぐり込みによりやや哚発地震 が発生している地域であるが，二重梁発地震面の存在は現時点では

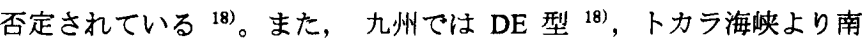
では DC 型 ${ }^{19)}$ の震源メカニズムが卓越するなど，地域性が見られる。

深さ $70 \mathrm{~km}$ 以上の地震の深さ別頻度分布を図 3 に示す。深さ方向 に一様に地震が発生するわけではなく，媣さ $200 \mathrm{~km}$ から $300 \mathrm{~km}$ 付近 に頻度が最小となる領域があり，それを過ぎると地震数は再び増加 し， $400 \mathrm{~km}$ 付近で極大に達する。また最大媣さは約 $600 \mathrm{~km}$ である。 次に発生頻度であるが，全期間の地震の総数は 434 個で, 全期間を 通じた平均個数は約 4 個/年, データの精度が高い 1926 年以後に限 ると約 5 個／年となっている。

\section{4. 被害歴}

\section{4-1 被害ランク}

被害ランクは宇津 ${ }^{3)}$ の分類に従い，A，B，C と設定した。ランク A は宇津のランク $1 ， 2$ に相当する軽微な被害を, ランクBは宇津 のランク 3 に相当する死者 19 名以下全壤家屋 999 棟以下の被害を示 す。ただし，宇津の资料は 1980 年までの地震を対象としているため， 1981 年以後は地震月報記载の被害の程度, および最大震度を表 2 の ように宇津の分類に対忍させて用いた。最大震度Vを宇津のランク 1，2に対応させたのは, 最大震度 IV を被害ランクに入れると被害 地震の数が 1981 年以後だけ急増するためである。また，震度 VI を ランク 3 に対応させているのは，釧路沖地震の死者数や被害状況を 至考としたもので，他のケースに一般的に当てはまるものではない。 宇津の被害ランクはランク 7 まであるが，今回のデータの中にはラ ンク 4 以上の地癑はなかった。ちなみに震源が浅い被害地震の例で は 1938 年の塩屋崎沖地震はランク 3,1968 年十勝沖地震と 1964 年 新潟地震はランク 4 である。

\section{4-2 地理被害が発生する条件}

以上のデータを用いて，震源が深い地震が被害地震になる条件を 検討する。マグニチュードと深さの関係に被害の有無およびラン

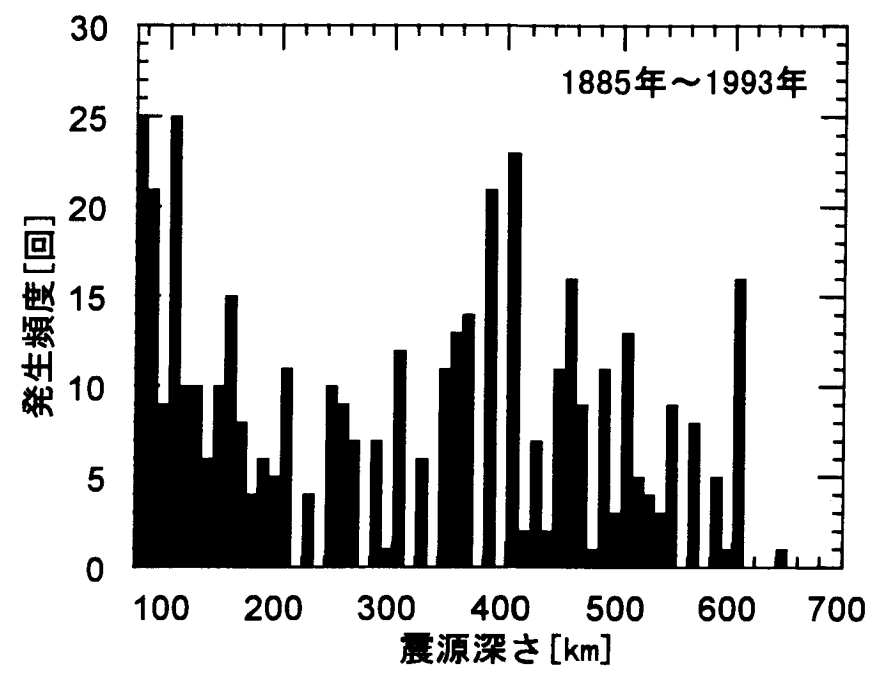

図3日本付近における $\mathrm{M} \geq 6$, 深さ $\mathrm{D} \geq 70 \mathrm{~km}$ の地震の発生頻度

○被害なし

○被客Aランク

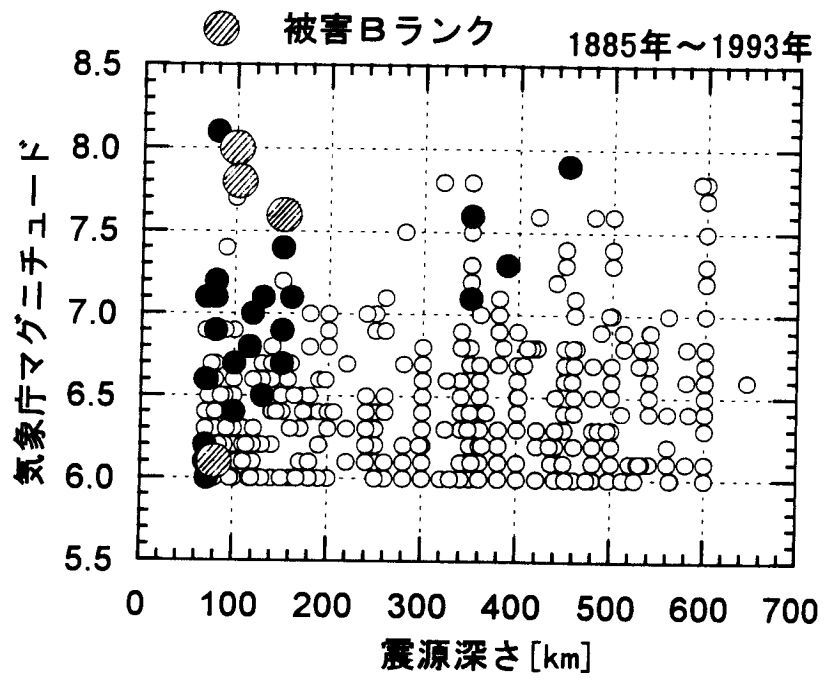

図 4 震源深さ, 地震規模と被害ランクの関係

表 2 被害ランクの定義

\begin{tabular}{|c|c|c|c|c|}
\hline \multicolumn{2}{|c|}{ 宇津の被害ランク ${ }^{3)}$ (1885 - 1980) } & \multirow{2}{*}{$\begin{array}{c}\text { 地震月報 } \\
\text { (1981-1984) }\end{array}$} & \multirow{2}{*}{$\begin{array}{c}\text { 地震月報 } \\
(1985-1993)\end{array}$} & \multirow{2}{*}{$\begin{array}{l}\text { 本研究の } \\
\text { 被害ランク }\end{array}$} \\
\hline ランク & 被害状況 & & & \\
\hline 1 & : Slight damage & \multirow{2}{*}{ Slight damage } & \multirow{2}{*}{ 最大震度 = V } & \multirow{2}{*}{ A } \\
\hline 2 & : Light damage & & & \\
\hline 3 & $\begin{array}{l}\text { 2-19 persons killed or } \\
\text { 2-999 houses completely destroyed }\end{array}$ & $\begin{array}{c}\text { この期間に該当する地 } \\
\text { 震がない }\end{array}$ & 最大震度 = VI & B \\
\hline 4 & : 20-199 person killed & \multicolumn{2}{|c|}{ この期間に該当する地震がない } & $\mathrm{C}$ \\
\hline
\end{tabular}


クを示した結果を図 4 に示す。地震の数が極大值を示す梁さ $400 \mathrm{~km}$ 付近にランクAの軽微な被害を出した地震がいくつかあるが, 他の 被害地興の全ては $150 \mathrm{~km}$ 以内の深さで発生している。唯一 $M=6$ ク ラスでランクBに分類されている地震は 1980 年に発生した千菜県中 部地震であり，4-3 で述べるように被害はそれほど大きいものでは ない。このことから, 哚さ $70 \mathrm{~km}$ 以上の地震が相当の被害を起こす条 件は, 地震規模が $\mathrm{M}=7.5$ 以上で深さが $150 \mathrm{~km}$ 以内のやや深発地震 であり，1993 年釗路沖地震も含め 1885 年以後 3 回生じている。表 3 に被害地震のリストをまとめて示す。

\section{4-3 主な地篗被害}

表 3 に示した被害地震の震央を図 5 に示す。図中の黒丸はBラン クで比較的被害が大きかった地震の震央である。尚，地図の簀囲の 関係から石垣岛付近の 2 つの地震がプロットされていないが，いず れも被害のランクはAで軽微なものである。また，千帛列岛のエト ロフ岛で 1958 年に発生した $M=8.1$ の地震は，梁さが $80 \mathrm{~km}$ と樑いに もかかわらず低角逆断層型の地震である ${ }^{20)}$ 。4つのBランクの地震 のうち，北海道の一つは 1993 年釧路沖地震である。図から分かるよ うにこの付近では以前から被害を伴うやや梁発地震が度々発生して いる。被害の詳細については各種調査報告書（例えば文献 2)）にあ りここでは省略するが, 死者 2 人, 負侮者数百人, 全壊住家十棟余 り，被害住家数百棟の被害である。

その他のBランクの地震を年代順に見ると, 最も古い地震は

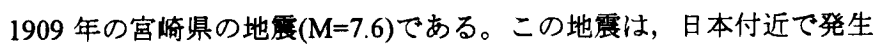

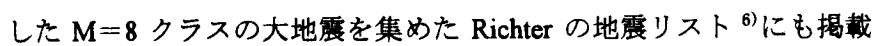
されている。新編日本被害地震総臨 ${ }^{21)}$ の記述によれば，九州を中心 に遠く岡山県でも全壤家屋が出たとのことである。さらに翌々年の 1911 年に発生した喜界息の地震( $\mathrm{M}=8.0)$ の規模は更に大きく, Richter のリストでは $\mathbf{M = 8 . 7}$ となっている。総临の震度分布を見ると, 震源 直上の奄美大岛付近では震度 VI で 1993 年釧路沖地鹿と同様である

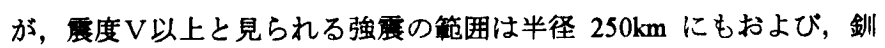
路沖地震のそれが $150 \mathrm{~km}$ 程度であるのと比べるとはるかに大きい。 本報で抽出した地震の中では最も強い地震動を発生させたと考えら れる。また，辰源が梁いにも関わらず津波を発生させていることか ら, 震源のすべりは釧路沖地呸のように水平運動卓越ではなく上下 運動卓越であったのかもしれない。また, 九州一琉球列島のやや深 発地蜄の発生の特徽から, 先の宮崎県の地震は $\mathrm{DE}$ 型, 二の地震は DC 型の震源メカニズムであった可能性が考えられる。

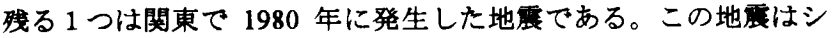
ヨック死で 2 人の死者を出したために宇津 ${ }^{3)}$ がランク 3 に分類して いるが, 被害の規模は他の 3 地震に比べて非常に小さい。この地震 はメカニズム解が求められているが ${ }^{22)}$, 震源樑さが $80 \mathrm{~km}$ と深いに もかかわらず低角逆断層型を示している。これは, もぐり込む太平 洋プレートとフィリピン海プレートがこすれ合って起こったことに よるためと考えられ, 他の地域で発生するやや哚発地震の震源メカ ニズムとは異なっている。

\section{4-4 泟が深い可能性のあるその他の被吾地震}

以上の検郡は 3-1 で述べたデータに基づいて検討した結果である。
表 3 日本付近で発生したやや媣発, 深発地震と被害ランク

\begin{tabular}{|c|c|c|c|c|c|c|c|c|}
\hline \multicolumn{3}{|c|}{ 発震時 } & \multicolumn{2}{|c|}{ 震央位置 } & \multirow[b]{2}{*}{ 震央地名 } & \multicolumn{3}{|c|}{ 深さ 被害 } \\
\hline$Y$ & D & $\mathrm{H}$ & Lon. & Lat. & & $\mathbf{M}$ & $\mathrm{km}$ & ランク \\
\hline 1898 & 1204 & 145 & 131.1 & 32.7 & 熊本県北部 & 6.7 & 150 & *A \\
\hline 1899 & 324 & 1305 & 131.1 & 31.8 & 宮崎県南部 & 6.4 & 100 & $* A$ \\
\hline 1906 & 121 & 2249 & 137.0 & 34.0 & 三重県沖 & 7.6 & 350 & $* A$ \\
\hline 1907 & 706 & 46 & 145.5 & 43.7 & 根室海峡 & 6.7 & 100 & ${ }^{*} \mathrm{~A}$ \\
\hline 1907 & 1223 & 1013 & 145.0 & 43.8 & 根室北部 & 6.9 & 150 & $* A$ \\
\hline 1909 & 1110 & 513 & 131.1 & 32.3 & 宮崎県西部 & 7.6 & 150 & *B \\
\hline 1911 & 615 & 2326 & 130.0 & 28.0 & 奄美大島付近 & 8.0 & 100 & $*^{*} \mathrm{~B}$ \\
\hline 1911 & 906 & 954 & 143.0 & 46.0 & 樺太南方沖 & 7.1 & 350 & ${ }^{*} \mathrm{~A}$ \\
\hline 1915 & 106 & 826 & 123.3 & 25.1 & 石垣島北方沖 & 7.4 & 150 & $*^{*} \mathrm{~A}$ \\
\hline 1928 & 521 & 129 & 140.0 & 35.6 & 東京湾北部 & 6.2 & 70 & ${ }^{*} \mathrm{~A}$ \\
\hline 1931 & 330 & 252 & 143.9 & 43.1 & 釧路西部 & 6.6 & 70 & ${ }^{*} \mathrm{~A}$ \\
\hline 1958 & 311 & 926 & 124.5 & 24.7 & 石垣島付近 & 7.2 & 80 & ${ }^{* A}$ \\
\hline 1958 & 1107 & 758 & 148.5 & 44.3 & 択捉島沖 & 8.1 & 80 & *A \\
\hline 1961 & 812 & 51 & 145.6 & 42.9 & 根室沖 & 7.2 & 80 & $*^{*} \mathrm{~A}$ \\
\hline 1964 & 623 & 1026 & 146.5 & 43.0 & 根室沖 & 7.1 & 80 & *A \\
\hline 1965 & 1026 & 734 & 145.5 & 43.7 & 国後島南岸 & 7.1 & 160 & *A \\
\hline 1968 & 921 & 2206 & 142.8 & 42.0 & 日高沖 & 6.9 & 80 & *A \\
\hline 1972 & 229 & 1823 & 141.3 & 33.2 & 八丈島東方沖 & 7.1 & 70 & *A \\
\hline 1974 & 1109 & 623 & 141.8 & 42.5 & 胆振沖 & 6.5 & 130 & *A \\
\hline 1979 & 713 & 1710 & 132.1 & 33.9 & 伊予灘 & 6.1 & 70 & ${ }^{*} \mathrm{~A}$ \\
\hline 1980 & 925 & 254 & 140.2 & 35.5 & 千葉県中部 & 6.1 & 80 & *B \\
\hline 1981 & 123 & 1358 & 142.2 & 42.4 & 日高地方西部 & 7.1 & 130 & ${ }^{*} \mathrm{~A}$ \\
\hline 1983 & 227 & 2114 & 140.2 & 35.9 & 茨城南部 & 6.0 & 72 & *A \\
\hline 1983 & 826 & 523 & 131.6 & 33.6 & 瀬戸内海西部 & 6.8 & 116 & A \\
\hline 1984 & 101 & 1803 & 136.8 & 33.6 & 東海道はるか沖 & 7.3 & 388 & ${ }^{*} \mathrm{~A}$ \\
\hline 1984 & 306 & 1117 & 139.2 & 29.3 & 鳥島近海 & 7.9 & 452 & $* A$ \\
\hline 1987 & 109 & 1514 & 141.8 & 39.8 & 岩手県中部 & 6.6 & 71 & A \\
\hline 1987 & 114 & 2003 & 142.9 & 42.5 & 日高山脈北部 & 7.0 & 119 & A \\
\hline 1993 & 115 & 2006 & 144.4 & 42.9 & 釧路沖 & 7.8 & 103 & B \\
\hline
\end{tabular}

*印は文献21に被害状況が記載 されている地震

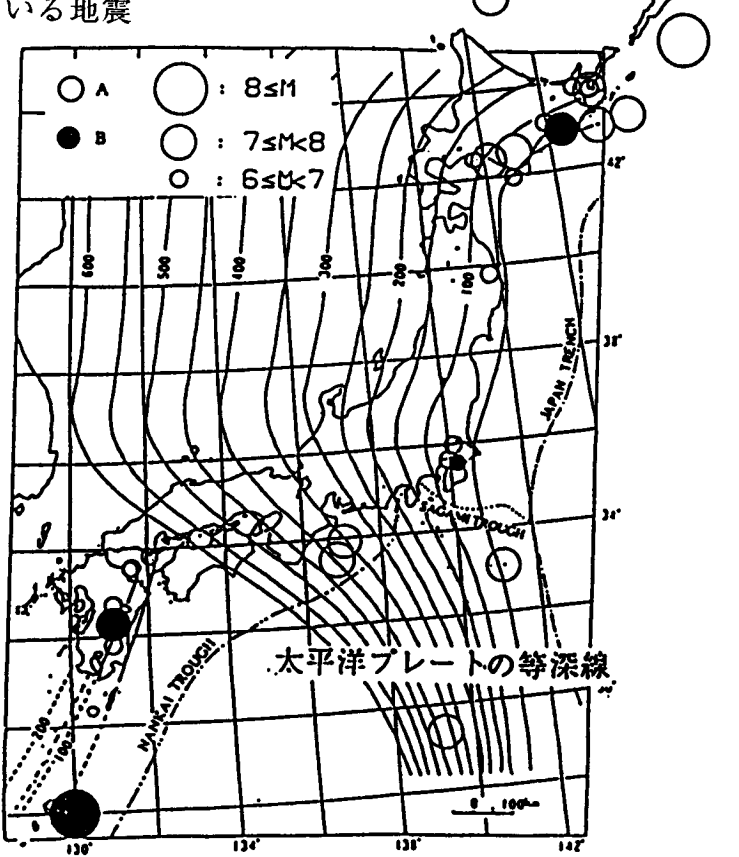

図 $5 \mathrm{M} \geq 6$, 深さ $\mathrm{D} \geq 70 \mathrm{~km}$ で被害を発生させた地震の 震央分布（1885 年 1993 年) 
データの選択で述べたように，古い時代には震源深さが明確でなく 宇津 ${ }^{3)}$ が深さを $\mathrm{s}$ と判定した (表 1 参照) 地震の中にも比較的震源 が深いものが含まれている可能性もある。それらの地震のうち, 被 害程度が比較的大きいランク B，C（宇津のランクで 3 以上）に属 するものを表 4 の上段に示す。

表 4 の下段は, 1926 年以後の地震のうち, 地震月報には無いが, 宇津 ${ }^{4)}$ の资料之新編日本被害地震総臨 ${ }^{21)}$ に記载されている 2 地震お よび 1978 年 2 月の宮城県沖地震である。1978 年 2 月の宫城県沖地 辰は震源の哚さは $50 \mathrm{~km}$ と哚さから見るとやや哚発地震の範睛に入ら ないが，震源メカニズムはやや染発地震特有の DC 型を示す ${ }^{15)}$ ここに追加した。

表 4 の上段の地震の震央を図 6 に示す。この中で最も大きな被害 をもたらした地震は 1894 年のいわゆる明治東京地震であり, 発生域 ははっきりしないが，太平洋プレートとフィリピン海プレートが衝 突する領域で発生した可能性がある ${ }^{7}$ 。また，1895 年の茨城県南西 部の地震は震央位置から考えて，1894 年の地震々同じ領域または二 重深発地震面の上面の可能性もある ${ }^{17 。}$ 。次に 1905 年の芸与地震で あるが, この地震の発生域は, 図 6 のフィリピン海プレートの等深 度線からも分かるようにたいへん複雑な地域である。このため震源 深さも明確にはよく分からないが，この地震には津波の記録が無く， 規模からすれば，少なくとも普通の浅い地震ではないと考えられる。 この地域には，1857 年にも同規模の地震があるがこの地震にも津波

表 4 震源が墚い可能性があるその他の被害地震

\begin{tabular}{|c|c|c|c|c|c|c|c|c|}
\hline \multicolumn{3}{|c|}{ 発震時 } & \multicolumn{2}{|c|}{ 震央位置 } & \multirow[b]{2}{*}{ 震央地名 } & \multicolumn{3}{|c|}{ 深さ被害* } \\
\hline$Y$ & $\mathrm{D}$ & $\mathrm{H}$ & Lon. & Lat. & & $\mathbf{M}$ & & ランク \\
\hline 1894 & 620 & 1404 & 139.8 & 35.7 & 東京都東部 & 7.0 & $\mathbf{s}$ & $C(4)$ \\
\hline 1895 & 118 & 2248 & 140.4 & 36.1 & 茨城県南西部 & 7.2 & $\mathrm{~s}$ & $\mathrm{~B}(3)$ \\
\hline 1905 & 602 & 1439 & 132.5 & 34.1 & 安芸灘 & 7.3 & s & $\mathrm{B}(3)$ \\
\hline 1952 & 718 & 109 & 135.8 & 34.5 & 奈良県西部 & 6.8 & 60 & $B(3)$ \\
\hline 1926 & 6292 & 2326 & 127.0 & 27.0 & 沖縄島北西沖 & 7.5 & 130 & $A(1)$ \\
\hline 1947 & 927 & 101 & 123.2 & 24.7 & 台湾北東沖 & 7.4 & 95 & $\mathrm{~B}(3)$ \\
\hline 1978 & 2201 & 336 & 142.2 & 38.8 & 宮城県沖 & 6.7 & 50 & $\mathrm{~A}(2)$ \\
\hline
\end{tabular}

*括弧内は宇津 ${ }^{3)}$ による被害ランク

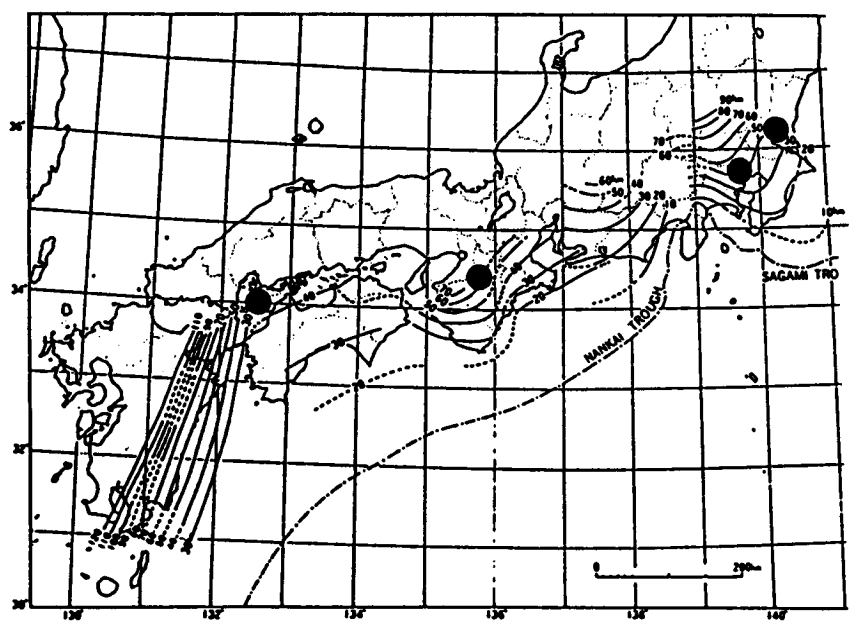

図 6 震源が深い可能性のあるその他の被害地震の震央分布 (コンターはフィリピン海プレートのもぐり込みの深さ)
の記録はない ${ }^{23)}$ 。最後は 1952 年の吉野地震である。この地震は深さ が 60km と決められているが，南海トラフから沈み込むフィリピン海 プレートの先端部で発生した梁くて被害をもたらした珍しい地震と 言われている ${ }^{24)}$ 。この地震の発生メカニズムも明らかになっていな い。以上, 表 4 の上段の地震は発生メカニズムが明かでないものば かりであるが，比較的震度分布の広がりが大きく，震源が梁いこと を示唆するものが多い。

\section{5. まとめ}

やや梁発・深発地震の発見の歴史から，最近の研究成果および過 去の被害歴を調査した。その結果を以下にまとめる。

（1）染さ $70 \mathrm{~km}$ 以上の地震の発生域は北海道，東北，関東地方におよ ぶ東北日本と九州から琉球列岛におよぶ西南日本が中心であり， $M=6$ 以上の発生頻度は年に 4 5 回である。

（2）東北日本のやや深発地震は二重面を形成し，上面が DC 型，下 面が DE 型の震源メカニズムをもつものが多い 8)，9)。これに対し 西南日本では二重面はなく, 九州では DE 型 ${ }^{18)}$, トカラ海峡より 南では DC 型 ${ }^{19)}$ の震源メカニズムが卓越する。また, 関東地方で は，太平洋プレートとフィリピン海プレートの相互作用により， 別のメカニズムをもつやや樑発地震も発生している ${ }^{17) 。}$

（3）梁さ $70 \mathrm{~km}$ 以上の地震が相当の被害 (ランク B) を起こす条件は, 地震規模が $M=7.5$ 以上で深さが $150 \mathrm{~km}$ 以浅である。1993 年釧 路沖地震も含め 1885 年以後 3 回生じている。釧路沖地震を除く 他の 2 回はいずれも西南日本で発生している。

（4）被害の程度は大きいもので宇津のランク ${ }^{3)} 3$ 程度であり，や や深発地震の可能性がある地震を入れても 4 が最高である。これ は 1938 年の塩屋岬沖地震 $(M=7.5)$ と同程度, 1968 年十勝沖地震 $(M=7.9)$ や 1964 年新潟地震 $(M=7.5)$ よりも小さい程度の被害にあ たる。

\section{胡辞}

本稿をまとめるにあたり弘前大学理学部付属地震火山観測所の小 菅正裕博士には，東北日本のやや深発地震に関する有益な料をお 送りいただきました。記して感謝の意を表します。

\section{参考文献}

1）宇津徳治 : 地震学, 共立出版, 1977

2) 鏡味洋史(代表)：1993 年釧路沖地震による被害の調查研究, 文 部省科学研究費突発災害の調査研究, 1993

3) 宇津徳治：日本付近のM 6.0 以上の地震および被害地震の表, 研菓報，57，401-463，1982

4) 和達清夫：哚層地震の存在と其の研究, 気象集誌, 第二号, 5 , 119-145, 1928

5）和達清夫：梁層地震の存在と其の研究（その二），気象集誌，第 二号, 6, 192-216, 1929 
6) Richter C. F : Elementary Seismology, W.H. Freeman and Company, 1958.

7) 松沢暢：岛弧の深部構造，地震特集号，44，145-158，1991

8) Hasegawa, A., N. Umino, and A. Takagi : Double-planed structure of the deep seismic zone in the Northeastern Japan Arc, Tectonophys., 47, 43-58, 1978

9) Hasegawa, A., N. Umino, and A. Takagi : Double-planed deep seismic zone and upper-mantle structure in the Northeastern Japan Arc, J. Roy. Astr. Soc., 54, 281-296, 1978

10) Veith, K. F. : The relationship of island arc seismicity to plate tectonics, Ph. D. thesis Southern Methodist University, Dallas, Tex, 1974

11) Engdahl, E. R. and C. H. Sholz : A double Benioff zone beneath the central Aleutians an unbending of the lithosphere, Geophys. Res., Lett.,4, 473-476, 1977

12) Sleep, N. H. : The double seismic zone in down going slabs and the viscosity of the mesosphere, J. Geophys, Res., 84, 4565-4571, 1979

13) Goto, K., H. Hamaguchi, and Z. Suzuki : Distribution of the stress descending plate in special reference to intermediate and deep focus earthquakes, Tohoku Geophys. J., 29, 81-105, 1983

14) Hasegawa, A., and A. Takagi : Comparison of Wadati-Benioff zone geometry and distribution of earthquake generating sress beneath Northeastern Japan and those beneath Western South America, Tohoku Geophys. J., 31, 1-18, 1987

15) Kosuga, M., T. Sato, A. Hasegawa, T. Matsuzawa, A. Susuki, Y.
Motoya : Spatial distribution of intermediate-depth earthquakes with horizontal or vertical nodal planes beneath northeastern Japan, Phys. Earth Planet. Int., 93, 63-89, 1996

16) Matsuzawa, T., N. Umino, A. Hasegawa and A. Takagi : Normal fault type events in the upper plane of the double-planed deep seismic zone beneath the Northeastern Japan Arc, J. Phys. Earth, 34, 85-94, 1986

17) 国立防災科学技術センター : 関東・東海地域のテクトニクスを 統一的に説明するモデル，地震予知連絡会報，51-58，1988

18）高橋道夫：九州下のやや深発地鹿面の非二重性, 地震 2,40 , 115-116， 1987

19）長宗留夫 : 九州一琉球列身におけるやや梁発地震とテクトニク ス, 地震 $2,40,417-424,1987$

20) 佐藤良輔編著 : 日本の地震断層パラメータハンドブック, 鹿岛 出版会, 1989

21）宇佐美龍夫：新編日本被害地震総览, 東京大学出版会, 1987

22) Ohta, T., H. Koshida, and M. Takemura : Determinant factors of a peak acceleration value on a strong motion record, 3rd Microzonation Conf., 496-506, 1982

23）渡辺偉夫 : 日本被害津波総临，東京大学出版会，1985

24）東京大学地震研究所：図説 日本の地震(1872-1972), 研究速報, 第 9 号, 1973

[1996 年 6 月 18 日原稿受理 1996 年 9 月 10 日採用決定 $]$ 